\title{
RITMO Y SINTAXIS EN EL VERSO LIBRE
}

\author{
María Victoria Utrera TORREMOCHA
}

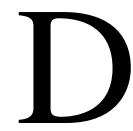
entro de la tipología de la versificación irregular y de la versificación amétrica, el verso libre aparece a menudo como la forma de expresión más cercana a las inquietudes de la poesía moderna, la forma que supuestamente cumpliría en el último siglo con las expectativas estéticas de un nuevo arte caracterizado, desde sus raíces románticas y pre-románticas, por la ruptura con la tradición anterior. El nacimiento del verso libre moderno se sitúa generalmente en Francia, aunque hay que advertir que se trata, en realidad, de un fenómeno internacional. En este sentido, junto a poetas franceses como Gustave Kahn (18591936), Jules Laforgue (1860-1887) o el belga Emile Verhaeren (1855-1916) destaca también Walt Whitman (1819-1892), quien tempranamente experimentaría con el verso libre en su obra Leaves of Grass, cuya primera edición, a la que seguirían otras con importantes variantes, es de 1855. El fenómeno versolibrista no surge de repente. Se va gestando desde tiempo atrás y está precedido por distintos experimentalismos métricos.

Son muchos los autores que han relacionado el versolibrismo tanto con la métrica acentual no silábica como con los intentos de recuperación del verso de ritmo hexamétrico. Es lo que sucede, por ejemplo, con la métrica bárbara de Carducci, o con los diferentes intentos de adaptación del hexámetro en la obra titulada Der Messias (1747-1773), de Klopstock, por ejemplo. ${ }^{1}$ Hay

${ }^{1}$ Sobre estos intentos hexamétricos y formas afines, vide M. Méndez Bejarano, La ciencia del verso. Teoría general de la versificación con aplicaciones á la métrica española, Buenos Aires, Talleres Gráficos de la Penitenciaría Nacional, 1906, pp. 
que considerar, además, la influencia de la prosa, la prosa litúrgica y los salmos bíblicos y de las traducciones poéticas en prosa. La obra de Klopstock, integrada por cinco himnos religiosos, publicados en 1758 y en 1759, sin rima y sin organización silábica, recibe su principal influencia de la Biblia, de ahí el empleo de los paralelismos como recurso estructural característico. Además, según ha estudiado Kohl, la cualidad rítmica de los himnos se explica por la unidad sintáctica de los versos, a lo que se suman las repeticiones que obedecerían a un principio retórico. ${ }^{2}$

En la literatura inglesa, aparte de algunas adaptaciones del hexámetro y de ciertos casos de versificación anisosilábica tónica, hay otras bases para el desarrollo del verso libre inglés. $\mathrm{Ph}$. Hobsbaum, por ejemplo, al referirse a los distintos tipos versolibristas en la tradición anglosajona, cita también el verso de carácter bíblico, con tendencia a repeticiones de palabras o frases, paralelismos, rimas internas, aliteraciones, etc. Su relación con la prosa lírica y exaltada es clara, así como con el perdido hexámetro, de ahí que se le llame cadenced verse. Como antecedentes del verso libre, W. Crombie indica además en el XviI los sermones de Donne y el estilo barroco de su prosa. ${ }^{3}$ El tipo de

226-235; B. Tomashevski, Teoría de la literatura, Madrid, Akal, 1982, p. 113; K.M. Kohl, Rhetoric, the Bible, and the Origins of free Verse. The early "Hymns" of Friedrich Gottlieb Klopstock, Berlín, Walter de Gruyter, 1990; B. Bjorklund, "Klopstock's poetic Innovations: The Emergence of German as a prosodic Language”, The Germanic Review, 56, 1 (1981), pp. 20-27; B. Lawder, Vers le vers, París, Nizet, 1993, pp. 175-210; M. Gasparov, Storia del verso europeo (1989), Bolonia, Il Mulino, 1993, pp. 303-304.

${ }^{2}$ Klopstock debió de ser consciente de la rudeza rítmica de estos versos y ya en las últimas versiones revisadas y publicadas de los himnos, en 1771, tiende a la regularidad en los pies métricos aunque el número de sílabas sea todavía irregular. Vide K.M. Kohl, op. cit., pp. 1-9 y 213-234.

3 Vide W. Crombie, Free Verse and prose Style. An operational Definition and Description, Londres-Nueva York-Sydney, Croom Helm, 1987, pp. 57-61; Ph. Hobsbaum, Metre, Rhythm and verse Form, Londres-Nueva York, Routledge, 1996, p. 112; J. Saavedra Molina, "Los hexámetros castellanos y en particular los de Rubén Darío”, Anales de la Universidad de Chile, 18 (1935), pp. 6-61; H.T. Kirby-Smith, The Origins of free Verse, Ann Arbor, University of Michigan Press, 1996, pp. 48-103; V. Zirmunskij, Introduction to Metrics (1925), La Haya, Mouton, 1966, pp. 192-195; O. Belic, Verso español y verso europeo. Introducción a la teoría del verso español en el contexto europeo, Santafé de Bogotá, Instituto Caro y Cuervo, 2000, p. 276. 
verso libre de carácter prosaico, fundamentado especialmente en el ritmo paralelístico y en las repeticiones de carácter retórico tiene una temprana manifestación en la obra de Walt Whitman titulada Leaves of Grass (1855). El verso de Whitman, anterior al verslibrisme francés, se fundamenta precisamente en el paralelismo originario de la métrica bíblica, y en especial de los Salmos y de sus traducciones inglesas en prosa. No cabe duda de la base prosaica de tales textos, los cuales, aunque en ocasiones presentan versos y grupos de versos de base rítmica métrica reconocible, no se diferencian de la prosa sino por su disposición tipográfica. Aunque algunos autores han querido ver en el tipo de verso libre de Whitman una herencia de la corriente poética de verso acentual isocrónico derivado del antiguo verso anglosajón aliterativo, no parece ser ésta una explicación adecuada al verso whitmaniano, cuya innovación respecto a la tradición versificatoria anterior reside más bien en la extremada longitud de algunos de sus versos y en el hecho de que dejan en un lugar secundario el ritmo métrico para favorecer el ritmo del pensamiento propio de la lógica prosística. ${ }^{4}$ Whitman no deja dudas sobre su intención anti-métrica, que se resume en el deseo de destruir y abandonar las viejas formas. En una carta a Emerson de 1856, que sirvió de segundo prefacio a Leaves of Grass:

${ }^{4}$ H.T. Kirby-Smith llama al verso libre de Whitman cadenced verse por su relación con la prosa y otros antecedentes como los bíblicos. Tampoco Gates, que considera el versículo de Whitman como verso, deja de ver la relación con el ritmo de la prosa. No hay que olvidar, en este sentido, la aproximación entre versículo y prosa, bien apreciable, por ejemplo, dentro de la tradición anglosajona, en la prosa de Oscar Wilde, quien ensaya el versículo bíblico de claro ritmo prosaico. Cfr. H.T. Kirby-Smith, op.cit., pp. 48-103; R.L. Gates, "The Identity of American free Verse: The prosodic Study of Whitman's Lilacs”, Language and Style. An International Journal, 18, 3 (1985), p. 248; M.V. Utrera Torremocha, Teoría del poema en prosa, Sevilla, Universidad de Sevilla, 1999, p. 219; M. Gasparov, op. cit., p. 304; E. Bollobas, Tradition and Innovation in American free Verse: Whitman to Duncan, Nueva York, State Mutual Book and Periodical Service, 1986; J. Silkin, The Life of metrical and free Verse in twentieth Century Poetry, Londres-Nueva York, McMillan Press-Saint-Martin’s Press, 1997, p. 4; C. Miller, “The iambic Pentameter Norm of Whitman's free Verse”, Language and Style, 15, 4 (1982), pp. 289-324. 
Old forms, old poems, majestic and proper in their own lands here in this land are exiles [...]. Authorities, poems, models, laws, names, imported into America, are useful to America today to destroy them, and so move disencumbered to great works, great days. ${ }^{5}$

La libertad que Whitman reivindica se cifra en la destrucción de los moldes métricos. En el prefacio a la edición de 1888 - “Mirada retrospectiva a los caminos recorridos”-, insiste, como en los anteriores, en que no hay reglas ni convenciones fijas para la poesía, cuya indefinición va unida a su esencial grandeza: «Ninguna de las definiciones que se han dado jamás encierra suficientemente al nombre poesía, ni hay regla o convención que puedan prevalecer tan absolutamente que no pueda surgir alguna gran excepción que las desobedezca y las eche por tierra». ${ }^{6}$ La expresión de un nuevo espíritu y de una nueva nación libre exige otra forma poética, para la cual reconoce la importancia de la literatura bíblica, además de otras fuentes. Whitman explica esta nueva forma, además, como expresión de la libre personalidad creadora:

En realidad, Hojas de Hierba [...] han sido principalmente el afloramiento de mi propia naturaleza emocional y personal; el intento, de principio a fin, de poner a una persona, a un ser humano (a mí mismo, en la segunda mitad del siglo xIx, en los Estados Unidos), libre, íntegra y fielmente en un libro. ${ }^{7}$

La tradición whitmaniana alcanza en la literatura anglosajona a buen número de autores; pero también está presente en el nacimiento del verslibrisme francés, y, desde luego, en otras literaturas occidentales. En el ámbito hispánico, por ejemplo, se ha indicado la presencia del versículo whitmaniano en diver-

\footnotetext{
${ }^{5}$ W. Whitman, Leaves of Grass, Nueva York, New York University Press, 1965, p. 734. Véase B. Lawder, op. cit., p. 98.

${ }^{6}$ W. Whitman, "Mirada retrospectiva a los caminos recorridos" (Prefacio a la edición de 1888), Hojas de Hierba, traducción al español de F. Alexander, Barcelona, Ediciones Mayol Puyol, 1981, pp. 59-60.

${ }^{7}$ Ib., p. 73.
} 
sos autores: Pablo Neruda, León Felipe, Vicente Aleixandre o Dámaso Alonso, por ejemplo, todos ellos con diferencias en el tipo de versículo empleado, según se tienda al ritmo prosaico o al versal. ${ }^{8}$ En Francia, además de otras influencias, la huella whitmaniana en los simbolistas es aceptada sólo por parte de algunos críticos, aunque se admite, generalmente sin reservas, su impronta en autores posteriores como Saint-John Perse, Claudel, Valéry o Gide. ${ }^{9}$ Aunque la influencia de Whitman se suele identificar con el verso largo o versículo bíblico, I. Paraíso considera que los simbolistas franceses no toman del poeta americano el versículo paralelístico ni su temática, sino sólo «su aspiración a la libertad métrica». ${ }^{10}$

Uno de los aspectos determinantes en la aparición del verso libre y el versículo es la valorización de la prosa literaria a lo largo de todo el siglo xıx, ya iniciada en épocas anteriores, que venía a confirmar la idea de que la poesía no tenía necesariamente que ser expresada en verso. El prosaísmo versolibrista y ciertas clases de verso libre de ritmo irregular derivan directamente de esta revalorización de los textos escritos en prosa. Desde el pre-romanticismo y el romanticismo muchos poetas quisieron encontrar una forma pura que devolviera al verso su sentido primitivo totalizador y que uniera, así, el misterio del verso a la pretendida espontaneidad y autenticidad de la prosa. Esta aspiración a fundir verso y prosa en una tercera forma expresiva se manifiesta en diversos autores y es un fenómeno especialmente apreciable en Francia, que se extiende a otras literaturas. Así, pues, el movimiento del versolibrismo en Francia se explicaría

${ }^{8}$ Véase I. Paraíso, El verso libre hispánico. Orígenes y corrientes, Madrid, Gredos, 1985, pp. 243 y 269.

${ }^{9}$ Cfr. G. de Torre, La aventura y el orden, Buenos Aires, Losada, 1948, pp. 119-120; R.L. Gates, art. cit., pp. 261-162. Sobre el versículo de Apollinaire, véase C. Scott, Vers libre: The Emergence of free Verse in France. 1886-1914, Oxford-Nueva York, Clarendon-Oxford University Press, 1990, pp. 269-294; J. Mazaleyrat, "Problèmes de scansion du vers libre: À propos d'un poème d'Apollinaire", en W.D. Lange y H.J. Wolf (eds.), Philologische Studien für Joseph M. Piel, Heidelberg, Winter, 1969.

${ }^{10}$ I. Paraíso, La métrica española en su contexto románico, Madrid, Arco/Libros, 2000, p. 186. 
más bien por el auge de la prosa poética, del poema en prosa y de las traducciones de poesía, vertidas en prosa, entre las que se encuentran las del propio Whitman, algunos de cuyos poemas se publicaron en 1886 en la revista La Vogue. No hay que olvidar también que en esta misma revista se publican en ese mismo año los poemas en prosa de las Illuminations de Rimbaud, que hace acompañar de dos poemas más, "Mouvement” y "Brise marine”. En éstos, especialmente en "Marine” (1875), muchos críticos han visto la primera manifestación del verso libre moderno. ${ }^{11}$ Del deseo de unir prosa y verso, característico de Mallarmé y otros poetas, se parte muchas veces para explicar teóricamente las formas líricas modernas, como el poema en prosa y el verso libre, las cuales se justificarían por el afán de volver a las formas puras primitivas. ${ }^{12}$ Una concepción análoga se plasma después en las poéticas de vanguardia, como en Jorge Luis Borges, o en las de algunos autores surrealistas que entienden prosa y verso -verso libre- como expresión original primitiva ligada a fuerzas terrestres primarias, según es apreciable en la poética de Vicente Aleixandre. Jorge Luis Borges, por ejemplo, relaciona ese mundo primero con la ausencia de límites entre prosa y poesía, donde habría sólo la magia y el misterio del todo: «En el principio de los tiempos, tan dócil a la vaga especulación y a las inapelables cosmogonías, no habrá habido cosas poéticas o prosaicas. Todo sería un poco mágico. Thor no era el dios del trueno; era el trueno y el dios.» ${ }^{13}$

La filiación del verso libre simbolista con la prosa poética y

${ }^{11}$ Véase I. Paraíso, “La silva y el modernismo”, en T. Albaladejo, J. Blasco y R. de la Fuente (coords.), El Modernismo. Renovación de los lenguajes poéticos, vol. I, Valladolid, Secretariado de Publicaciones de la Universidad de Valladolid, 1990, p. 111, La métrica española..., pp. 181-209, y El verso libre..., p. 14; J.-M. Bobillot, "Rimbaud et le 'vers libre”, Poétique, XVII, 66 (1986), pp. 199-216; M. Murat, "Rimbaud et le vers libre: Remarques sur l'invention d'une forme”, Revue d'Histoire Littéraire de la France, 100, 2 (2000), pp. 255-276.

${ }^{12}$ Vide Paraíso, El verso libre..., pp. 191-192. Véase M.V. Utrera Torremocha, op. cit., pp. 356-362.

13 J.L. Borges, “Prólogo” a El oro de los tigres (1972), en Obra poética. 1923/1985, Buenos Aires, Emecé Editores, 1989, p. 365. 
con el poema en prosa explica que el ritmo del verso libre sea en muchas ocasiones un ritmo basado en la sintaxis y la imagen. Como el verso libre, el poema en prosa de los simbolistas se fundamenta en la idea mallarmeana del ritmo y la música como bases de toda escritura poética. El ideal wagneriano de un arte total disuelve las fronteras entre formas expresivas y géneros. Los límites entre versículo, verso libre y poema en prosa, prosa rítmica, novela o drama se hacen cada vez más difusos. Los primeros simbolistas, en busca de una nueva expresión individual, mezclan, pues, verso regular, verso libre y poema en prosa. ${ }^{14}$ En efecto, una década después de haber mezclado poemas en prosa y verso libre en los Palais Nomades (1987), Gustave Kahn proclama la abolición del poema en prosa, con lo que el verso libre se erige entonces como modalidad poética mucho más moderna y afín a la expresión y la libertad personal. Con Kahn, poetas como Dujardin, Laforgue o Mockel, ven el género del poema en prosa como una etapa necesaria, como una especie de transición, para la llegada del verso libre. En este sentido, ya Mallarmé, que había experimentado con el alejandrino y el verso liberado, había anunciado la necesidad de crear una forma nueva que no fuera ni verso ni prosa, sino la expresión absoluta de la música interior. Este deseo se resolvió en su Un coup de dés, antesala simbolista de las vanguardias europeas y de la poesía visual. La relación entre la interioridad subjetiva del poeta y los experimentalismos métricos es evidente en "La música y las letras” (“La Musique et les lettres”), de 1894, donde relaciona el verso libre con el desequilibrio espiritual del hombre moderno y la modulación rítmica personal, que ha encontrado en la nueva forma su plenitud expresiva: «Un hermoso hallazgo, con el que queda, poco más o menos, clausurada la búsqueda de ayer, lo tenemos en el verso libre, modulación (digo a menudo) indivi-

${ }^{14}$ Cfr. I. Paraíso, La métrica española..., p. 185; M.V. Utrera Torremocha, op. cit., passim; S. Bernard, Le poème en prose de Baudelaire jusqu'à nos jours, París, Nizet, 1959, pp. 404-405. Sobre los inicios versolibristas franceses, vide H. Morier, "Vers libre", en Dictionnaire de poétique et de rhétorique, París, P.U.F., 1961, pp. 462-466. 
dual, ya que toda alma es un nudo rítmico». ${ }^{15}$

Las definiciones que poetas y estudiosos han dado a lo largo del tiempo del verso libre suelen presentar problemas por su ambigüedad, por la imposibilidad de ser aplicadas a distintas manifestaciones del verso libre y, muy especialmente, porque son en buena medida definiciones negativas, es decir, definiciones que no vienen a explicar el verso libre por sus valores y elementos distintivos respecto al verso regular, sino que sólo niegan la existencia de determinados elementos de éste en aquél. Definir el verso libre por negación del concepto de verso es implícitamente definir la prosa. Ante este hecho evidente, poetas $\mathrm{y}$ estudiosos afirman repetidamente que, fuera de las convenciones métricas tradicionales, a las que el verso libre escaparía, aún queda en él el ritmo. Pero, de nuevo las formas de entender el ritmo se multiplican, ya alejándose de cualquier referencia métrica, ya acercándose a ella.

La libertad, ya defendida por Whitman con un sentido a la vez literario y político, está presente en las primeras definiciones del verso libre, y junto a ella, la novedad, la sorpresa y la idea de que el nuevo verso es reflejo y expresión directa de la interioridad personal, por lo que su ritmo no obedecería a la realización de un canon previo, sino a la armonía interior, al ritmo personal del autor. Estas ideas aparecen tanto en Whitman como en los primeros versolibristas del simbolismo francés y se repetirán por buena parte de poetas y estudiosos posteriores para explicar cualquier tipo de versificación libre.

El primer teórico del versolibrismo francés es Gustave Kahn, cuyas ideas sobre el verso libre se recogen, entre otros escritos, en la respuesta que dio a la Enquête sur l'évolution littéraire de Jules Huret en 1891 o en el prefacio a sus Premiers poèmes de

${ }^{15}$ S. Mallarmé, Prosas, edición de J. del Prado, Madrid, Alfaguara, 1987, p. 211. Cfr. C. Scott, A Question of Syllables. Essays in nineteenth Century French Verse, Cambridge, Cambridge University Press, 1986, p. 157. Sobre la confusión verso y prosa en Mallarmé, vide M.V. Utrera Torremocha, op. cit., pp. 195 y ss.; W.Th. Elwert, "Mallarmé entre la tradition et le vers libre: Ce qu'en disent ses vers de circonstance”, en M. Parent (ed.), Le vers français au XXe siècle, París, Klincksieck, 1967, pp. 123-138. 
1897, donde aparecen bien sintetizadas sus ideas versolibristas. En el prefacio de 1897, señala la importancia de la nueva técnica versificatoria, que asocia a la armonía del ritmo individual:

L'importance de cette technique nouvelle, en dehors de la mise en valeur d'harmonies forcément négligées, sera de permettre à tout poète de conçevoir en lui son vers ou plutôt sa strophe originale, et d'écrire son rythme propre et individuel au lieu d'endosser un uniforme taillé d'avance et qui le réduit a n'être que l'élève de tel glorieux prédécesseur. ${ }^{16}$

Establece Kahn la idea de las células rítmicas, ya liberadas de la antigua prosodia y de las reglas de acentuación tradicionales, células que llama «cellules organiques»" ${ }^{17}$ y que sirven de fundamento a una nueva técnica versificatoria. Las "cellules organiques" serían el equivalente a las medidas antiguas de la prosodia, pero libres del patrón métrico prefijado, de las reglas convencionales. La unidad rítmica del verso, para Kahn, se basaría en la unidad de sentido, de manera que el poeta libre prescindiría del encabalgamiento al dejarse arrastrar por el sentido de la frase breve, producto del impulso interno. Así, la unidad del verso se define como «un fragment le plus court possible figurant un arrêt de voix et un arrêt de sens»..$^{18}$ Estas unidades de sentido se unen para formar un todo coherente que permita calificarlas como versos. La cohesión de estas unidades en la totalidad del poema, necesaria para que éste se constituya como tal, se lograría por las relaciones fónicas, la armonía de sonidos entre los versos, es decir, por las aliteraciones. Este principio armónico se conjuga con otro principio interno que cohesiona el poema y sus estrofas: el de la unidad de sentido, no ya de cada verso en particular, sino

${ }^{16}$ G. Kahn, "Préface sur le vers libre”, en Premiers poèmes, París, Mercure de France, 1897, p. 28. Véase B. Lawder, op. cit., p. 54; F. Carmody, "La doctrine du vers libre de Gustave Kahn”, Cahiers de l'Association Internationale des Études Française, 21 (1969), pp. 37-50.

${ }^{17}$ G. Kahn, art. cit., loc. cit., p. 24. Cfr. B. Lawder, op. cit., pp. 54-55.

${ }^{18}$ G. Kahn, art. cit., loc. cit., p. 26. 
de cada conjunto estrófico que integra el poema, de modo que, respecto al sentido, hay también una pauta interna de organización. ${ }^{19}$ Pensamiento y forma se unen no sólo en el verso, sino en la estrofa y en el poema. Es así como el impulso del pensamiento y, con él, el ritmo de la sintaxis se imponen en la elaboración de la unidad rítmica versal y de la unidad estrófica para construir el poema de versificación libre. Así lo expuso también en 1891:

Qu'est-ce qu'un vers? C’est un arrêt simultané de la pensée et de la forme de la pensée.- Qu'est-ce qu'une strophe? C'est le développement par une phrase en vers d'un point complet de l'idée.- Qu'est-ce qu'un poème? C'est la mise en situation par ses facettes prismatiques, qui sont les strophes, de l'idée tout entière qu'on a voulu évoquer. ${ }^{20}$

Sin embargo, Kahn insiste en que, a pesar de la importancia concedida al ritmo de pensamiento, el verso libre no es prosa cortada tipográficamente en forma de verso. El juego aliterativo de los sonidos impediría tal asimilación al ritmo de la prosa. ${ }^{21}$

En consonancia con estas ideas, el también poeta y crítico versolibrista Édouard Dujardin en la obra de 1922 titulada Les premiers poètes du vers libre resume las inquietudes que animaban la práctica de los versolibristas de fines del XIx y principios del xx. Como Kahn y otros autores, hace depender el verso libre de los experimentos de Mallarmé y, en especial, de Verlaine respecto al alejandrino y proclama la entera libertad del poeta

\footnotetext{
${ }^{19}$ Véase $i b .$, pp. 26-27.

${ }^{20}$ G. Kahn, “Enquête sur l'évolution littéraire”, L'Écho de Paris, 4 de julio de 1891, p. 2; J. Huret, Enquête sur l'évolution littéraire (1891), ed. de D. Grojnowski, París, Corti, 1999, p. 379.

${ }^{21}$ Cfr. Ib. Véase B. Lawder, op. cit., pp. 55-56. Los ataques al verso anterior y la defensa de la libertad personal como base del verso libre se repiten en autores coetáneos: René Ghil, Vielé-Griffin, Adolphe Retté, Henri de Régnier, Jean Moréas, etc., que, con otros autores, relacionan siempre el verso libre con la expresión de un ritmo personal. Cfr. B. Lawder, op. cit., pp. 52-54; S. Bernard, op. cit., p. 488; M. Parent, "La versification française au XX $X^{\mathrm{e}}$ siècle a-t-elle évolué d'une façon comparable à celle du XVIe siècle. Des recherches analogues. Des trouvailles nouvelles”, en M. Parent (ed.), op. cit., pp. 293; C. Scott, Vers libre: The Emergence..., pp. 120-126.
} 
en la expresión de su ritmo personal, defendiendo la abolición de la rima, de la cesura entre hemistiquios y de la igualdad en el número de sílabas de los versos, así como la eliminación en la escansión de la $e$ muda si ésta no se pronuncia. Estos aspectos, entre otros, diferenciarían el verso libre simbolista del "verso liberado" anterior. ${ }^{22}$ Como en Kahn, es fundamental que la unidad versal se corresponda con una unidad sintáctica. El verso, unidad musical y unidad de visión y de sentido, se diferenciaría, así, de la prosa, y volvería al mismo tiempo a su verdadera esencia primigenia, a su unidad primitiva -“unité primitive"- ${ }^{23}$ Contrariamente a lo que podría parecer, la unidad sintáctica es lo que hace posible la definición del verso como verso. El poeta deberá evitar a toda costa el encabalgamiento, que acercaría el verso libre a la prosa al romper su unidad esencial. ${ }^{24}$

El problema del encabalgamiento ha sido repetidas veces tratados a propósito del verso libre. Frente a los primeros teóricos versolibristas franceses, el encabalgamiento en el verso libre ha sido entendido a menudo como recurso expresivo fundamental, que vendría a atenuar aún más, si cabe, el ritmo métrico aproximativo de algunos poemas versolibristas de base endecasilábica, efecto que es perceptible igualmente con un uso excesivo del encabalgamiento en los poemas de versificación regular. ${ }^{25}$ No obstante, la unidad del verso en estos casos nunca llega a perderse gracias a la equivalencia dada entre la igualdad silábica de los versos. En la bibliografía anglosajona sobre el verso libre se

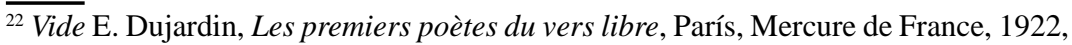
pp. 8-9.

${ }^{23}$ Ib., pp. 12-13 y 58. Véase B. Lawder, op. cit., pp. 56-58; C. Scott, Vers libre: The Emergence..., pp. 145-150.

${ }^{24}$ Vide E. Dujardin, op. cit., pp. 12-13 y 27; B. Lawder, op. cit., pp. 57-58. Es necesario distinguir los experimentalismos del verso "liberado" del puro versolibrismo. Para Mazaleyrat el vers libéré es un verso “de mètre traditionnel (ex.: “alexandrin libéré”), mais de formule assouplie par une prosodie variable, un large usage des discordances, et des changements de rythme fréquents (du binaire au ternaire notamment)" (J. Mazaleyrat, Éléments de métrique française, París, A. Colín, 1965, p. 158). Cfr. S. Bernard, op. cit., pp. 367-370; I. Paraíso, El verso libre..., pp. 14 y 20, y La métrica española..., p. 187; P. B. Garnelo, "El modernismo literario español”, La ciudad de Dios, XCVI (1914), pp. 34-46, 331-342 y 345-359.

${ }^{25}$ Véase J. Domínguez Caparrós, Diccionario de métrica española, Madrid, Paraninfo, 1985 , pp. 54-55. 
ha estudiado especialmente el encabalgamiento por su frecuente aparición en numerosos poetas, hasta el punto de que a veces se ha visto como un rasgo de estilo de los autores versolibristas. En la tradición inglesa y americana se habla de un vigoroso enjambed free verse, usado por poetas como Williams, Frank O'Hara, Robert Bly, Robert Creeley o William Merwin. ${ }^{26}$ Hartman se refiere a distintos fenómenos de tensión o counterpoint en el verso libre, entre los que incluye el encabalgamiento, característico del segundo momento en el desarrollo del versolibrismo, frente a un primer momento en el cual sí se hubiera respetado, como en la poesía francesa, la unidad gramatical. Precursores de esta forma versolibrista encabalgada serían Whitman, Blake, Cowley, Arnold, Henley y MacPherson, además de Milton. ${ }^{27} \mathrm{La}$ moda del encabalgamiento en el siglo xx ha llevado a algunos críticos a distinguir el verso libre sintáctico del verso libre antisintáctico. ${ }^{28}$ Según J. Cohen ${ }^{29}$ el encabalgamiento en el verso libre sería una clara desviación de la gramaticalidad que vendría a confirmar la esencial agramaticalidad de la poesía en verso. José Domínguez Caparrós ha destacado también el valor expresivo del encabalgamiento, pero indica acertadamente que es un «fenómeno puramente estilístico, ya que su aparición no está regulada por las normas de la métrica y sólo depende de la voluntad o la intención del poeta». ${ }^{30}$ En efecto, ni el encabalgamiento ni la esticomitia son privativos de la versificación libre.

En 1909, después de la encuesta de J. Huret (1891), se publica una encuesta sobre el verso libre, preparada por Filippo Tommaso Marinetti, Enquête internationale sur le vers libre, en la que aparecen nuevos nombres que defienden el verso libre. En ella se mantiene, caso de Camille Mauclair, por ejemplo, la idea del verso libre como expresión del ritmo personal, de acuerdo

${ }^{26}$ Véase P. Fussel, Poetic Meter and poetic Form, edición revisada, Nueva York, McGraw Hill, 1979, pp. 81-83.

${ }^{27}$ Cfr. Ch.O. Hartman, Free Verse. An Essay on Prosody, Princeton, Princeton University Press, 1980, pp. 14-28 y 52-80.

${ }^{28}$ Véase M. Gasparov, op. cit., p. 307.

${ }^{29}$ Cfr. J. Cohen, Estructura del lenguaje poético, Madrid, Gredos, 1970, pp. 53-71.

30 J. Domínguez Caparrós, op. cit., p. 55. 
con los impulsos psicofisiológicos. Como Kahn, condena el encabalgamiento de la poesía anterior y no niega la presencia del verso regular, sometido a la unidad de sentido, en los versos libres. Henri Ghéon, sin embargo, rechaza la libertad individual del verso libre y su propia condición de verso a no ser dentro de la estrofa, que sería expresión armónica al someterse a la unidad lógica del pensamiento. ${ }^{31}$ Pero todas estas afirmaciones y otras posteriores parecen, no obstante, demasiado vagas y faltas de precisión. Hay que advertir, además, que la estructura pseudoestrófica no es definitoria de la composición en verso, pues ya aparece en las primeras manifestaciones de los poemas en prosa, como sucede, por ejemplo, en el Gaspard de la Nuit, de Aloysius Bertrand. ${ }^{32}$

En el ámbito hispánico Ricardo Jaimes Freyre en sus Leyes de la versificación castellana (1912) hace un intento de sistematización del verso libre y se refiere a él como verso polimorfo, un verso sin ritmo o arritmo. Este "verso", que realmente responde a la idea de libertad y del que él mismo se atribuye la invención en 1894 sería «una forma diferente del verso y de la prosa», una "tercera forma” en la que se mezclan todos los períodos prosódicos y en la que cada unidad se ajusta a una sola idea o imagen, de manera que cada pensamiento crea su propia forma. ${ }^{33}$ Es evidente que el poeta modernista tiene en cuenta las ideas simbolistas de Vielé-Griffin o Kahn sobre la necesaria unidad sintáctica del verso libre. A este respecto, Jaimes Freyre cita como antecedentes del verso libre arrítmico el ritmo ideológico de los hebreos, árabes, chinos y otros pueblos primitivos, y los versículos de herencia bíblica de San Jerónimo y otros autores.

También Rubén Darío liga el verso libre al ritmo interior y al pensamiento. Así, a propósito de su poema "Heraldos", de Prosas profanas, expone en Historia de mis libros: «En Heraldos de-

${ }^{31}$ Cfr. F.T. Marinetti, Enquête internationale sur le vers libre, Milán, Poesia, 1909, pp. 69-71. Véase también É. Verhaeren, en F.T. Marinetti, ib., p. 36; R. de Souza, ib., p. 99.

${ }^{32}$ Véase M.V. Utrera Torremocha, op. cit., pp. 58-68.

${ }^{33}$ Cfr. R. Jaimes Freyre , "Del moderno verso libre o polimorfo", Poemas. Leyes de la versificación castellana, México, Aguilar, 1974, pp. 223-240. 
muestro la teoría de la melodía interior. Puede decirse que en este poemita el verso no existe, bien que se imponga la notación ideal. El juego de sílabas, el sonido y el color de las vocales, el nombre clamado heráldicamente, evocan la figura oriental, bíblica, legendaria, y el tributo y la correspondencia». ${ }^{34} \mathrm{~A}$ la luz de estas palabras, parece clara la herencia simbolista de Mallarmé, así como de los primeros versolibristas franceses: melodía interior, juegos de sonidos, etc.

Tras las primeras manifestaciones de fines del siglo xIx y de principios del siglo xx, el versolibrismo se extiende y desarrolla con la llegada de las vanguardias literarias, hasta llegar de forma definitiva la destrucción del concepto de verso. Muchos de los tópicos aplicados al verso libre se dejan ver en la teoría de otros ámbitos artísticos. ${ }^{35}$ La teoría y la práctica literarias tienen un correlato en la pintura y su tendencia a la transformación de las antiguas formas y a la abstracción como expresión de la individualidad. La metamorfosis del verso se conjuga en la nueva literatura con la problematización del sentido y la ruptura con el concepto de mimesis.

Las expectativas creadas en torno al verso libre se corresponden plenamente con la libertad y la ruptura de la vanguardia. Así lo manifiesta, por ejemplo, E. Díez-Canedo: «Hemos llegado, en poesía, al sumo de las libertades. Adolescentes que se horrorizarían de componer un soneto a semejanza de los de Lope, no vacilarían en lanzar, después de Marinetti, a voleo, palabras en libertad». ${ }^{36}$ En muchos casos, estas palabras en libertad

${ }^{34}$ R. Darío, Obras Completas. Crítica y ensayo, vol. I, Madrid, Afrodisio Aguado, 1950, p. 209. Paraíso incluye "Heraldos" dentro de la modalidad de verso libre paralelístico menor. Con Pedro y Max Henríquez Ureña, y frente a T. Navarro Tomás y a las propias dudas de Darío, considera este poema como escrito en verso y no en prosa, arguyendo que la "música de la idea", es decir, el ritmo de pensamiento, concretamente el paralelismo, es suficiente base rítmica, sin necesidad de otros ritmos versales, para entender estas líneas como auténticos versos. Para la autora, con "Heraldos” se iniciaría en la poesía hispánica el verso libre paralelístico, de carácter retórico, caracterizado por «renunciar a los ritmos fónicos versales (metro, acento, rima, estrofa) y anclarse, en cambio, en procedimientos retóricos (paralelismos, acumulaciones, etc.)». (I. Paraíso, El verso libre..., p. 106.)

${ }^{35}$ Véase ib., p. 271. 
se transforman en prosa poética, en caligramas, en discursos fragmentados que no pueden llegar a definirse ni desde los presupuestos de la prosa ni desde los del verso. Estos extremos aparecen, en efecto, en muchos de los textos que reivindican las palabras en libertad de Filippo Tommaso Marinetti y de los futuristas (1909), anulando, así frecuentemente el verso en favor de los juegos tipográficos. La premisa estética de las palabras en libertad apunta indudablemente a la ruptura no sólo del verso tradicional sino del mismo concepto de prosa. ${ }^{37}$ Evidentemente, junto al futurismo, otras vanguardias incidían en esta misma misión destructora, caso de Dadá, que, con la asunción del tedio y del vacío, quiere abolir todo sistema establecido. ${ }^{38}$

En España e Hispanoamérica los escritos teóricos de los nuevos poetas ultraístas y creacionistas muestran un talante rupturista equivalente. En el artículo "Ultraísmo”, Jorge Luis Borges señala entre los puntos básicos del grupo la reducción de la lírica a lo que considera su elemento primordial: la metáfora. ${ }^{39}$ Aparte de la clara relación con el movimiento imaginista del modernism inglés y su defensa de la imagen, hay que señalar que se cumple ya aquí la consecuencia última de la concepción simbolista de la poesía. Dejar la imagen, el símbolo, el procedimiento a secas y eliminar otros elementos que se consideran innecesarios. Así, la esencia de lo lírico se identifica con la imagen, mientras que

${ }^{36}$ E. Díez-Canedo, “Tópicos”( 1921), en I. Paraíso, ib., p. 270.

${ }^{37}$ El futurismo implica la ruptura del verso con un efecto inarmónico que atenta contra la simetría clásica en favor del movimiento y de las palabras en libertad: el "verbolibre” y el verso sin ataduras o verso libre en su sentido más nato irían de la mano. En esta línea, Ramón Gómez de la Serna, siguiendo a Marinetti señala: «La danza futurista será 'inarmónica, desgraciada, asimétrica, dinámica, verbolibre'». (R. Gómez de la Serna, “Futurismo”, en Ismos, Madrid, Guadarrama, 1975, p. 110.)

${ }^{38}$ Ib., p. 248. Véase también A. Gómez Torres, La retórica de la nada: En torno a la poética de las vanguardias, Málaga, Publicaciones del Congreso de Literatura Española Contemporánea, 1998.

${ }^{39}$ Véase J.L. Borges, "Ultraísmo”, Nosotros (Buenos Aires), año XV, vol. XXXIX, 151 (1921), en O. Collazos, Los vanguardismos en la América Latina, Barcelona, Península, 1977, p. 135; P. Aullón de Haro, La modernidad poética, la vanguardia y el creacionismo, Málaga, Universidad de Málaga, 2000, p. 193; I. Paraíso, El verso libre..., p. 276; T. Navarro Tomás, Métrica española, Barcelona, Labor, 1991, p. 471. 
el verso, además de otros aspectos, deja de ser un procedimiento elemental de la poesía para convertirse en un mero ornamento accesorio $\mathrm{y}$, por lo tanto, ajeno al verdadero núcleo poético, ornamento del que hay que liberar al poema en favor de la imagen pura y simple. En este sentido, se manifiestan poetas como Guillermo de Torre, que ve en la imagen creada por la metáfora algo desligado de la realidad objetiva, y años después, José Ortega y Gasset definiría la poesía como «el álgebra superior de las metáforas». ${ }^{40}$

La cuestión del ritmo en el verso libre se ve dificultada con la llegada de las vanguardias y el llamado verso libre de imágenes. Especialmente, el creacionismo se acoge plenamente al verso libre moderno. ${ }^{41}$ Como poeta de vanguardia española que lleva al extremo la máxima de Marinetti de las palabras en libertad, destaca Vicente Huidobro, no sólo por la novedad de sus combinaciones tipográficas sino por el empleo del vanguardista verso de imágenes libre, el tipo versolibrista más característico de la vanguardia, ${ }^{42}$ cuyo desarrollo se explica por el rechazo de la poesía anterior. La negación de la estética precedente se manifiesta en varios textos de Huidobro especialmente significativos: el conocido manifiesto "Non serviam”, el prefacio al poema Adán o los escritos recopilados en Pasando y Pasando y Manifiestos. En el "Prefacio” al poema Adán, de 1916, Huidobro desestima absolutamente la poesía retórica de los modernistas:

Todos los metros oficiales me dan idea de cosa falsa, literaria, retórica pura. No les encuentro espontaneidad [...].

La poesía castellana está enferma de retoricismo; agonizante de aliteratamiento, de ser parque inglés y no selva majestuosa, pletórica de fuerza y ajena a podaduras, ajena a mano de horticultor. ${ }^{43}$

Es interesante hacer notar la exaltación de la selva como

${ }^{40} \mathrm{~J}$. Ortega y Gasset, La deshumanización del arte y otros ensayos de estética, Madrid, Revista de Occidente, 1976, p. 43. Cfr. A.M. Gómez Torres, op. cit., pp. 68 y ss; P. Aullón de Haro, op. cit., p. 193.

${ }^{41}$ Cfr. T. Navarro Tomás, op. cit., pp. 471-472.

${ }^{42}$ Véase I. Paraíso, El verso libre..., pp. 274-275.

${ }^{43}$ V. Huidobro, "Prefacio" a Adán, en Poética y estética creacionistas, selección y prólogo de V. Quirarte, México. U.N.A.M., 1994, p. 32. Cfr. P. Aullón de Haro, 
ejemplo del desorden que habrá de traducirse en una forma equivalente. Por ello cree Huidobro que el verso libre es necesario en la composición del nuevo tipo de poesía que quiere hacer en Adán. Es entonces cuando explica el ritmo en un sentido amplio, supeditándolo, como otros autores versolibristas, a la armonía de la estrofa, de modo que la idea poemática despliegue en el conjunto lírico un ritmo propio. ${ }^{44}$ La relación de la nueva poesía, una poesía del futuro, con la selva tiene que ver con la comunión que se establece entre el personaje de Adán y la naturaleza. La correspondencia de carácter panteísta entre el alma individual y los componentes naturales se concreta, además de en la selva, en el mar, nueva fuerza primigenia de vida, que, como en otros autores anteriores, queda asociado al verso libre. Lo primitivo vital, pues, pleno de autenticidad y sin ningún retoricismo, ha de ser expresado en verso libre, forma espontánea única capaz de expresar el absoluto de la nueva realidad adánica. ${ }^{45}$

En un artículo sobre el futurismo, Huidobro alaba precisamente, frente a las muchas críticas del movimiento, la proclamación de Marinetti del verso libre. ${ }^{46}$ Pero la destrucción del verso y de la lógica deriva en la plena desintegración de las palabras y su significado. Es lo que sucede, por ejemplo, en el "Canto VII" de Altazor (1931):
Ai aia aia
ia ia ia aia ui
Tralalí
Lali lalá
Aruaru
urulario
Lalilá
Rimbibolam lam lam

op. cit., pp. 177 y ss., y "La teoría poética del creacionismo”, Cuadernos Hispanoamericanos, 427 (1986), pp. 49-73.

${ }^{44}$ Véase V. Huidobro, op. cit., pp. 30-31.

${ }^{45}$ Cfr. Ib., p. 30.

${ }^{46}$ Véase ib., pp. 117-118; P. Aullón de Haro, op. cit., p. 199. 
Uiaya zollonario

lalilá

Monlutrella monluztrella

Montresol y mandotrina

lalolú

Ai ai

Montesur en lasurido

Montesol

Lusponsedo solinario

Al lado del verso libre que rompe en muchos casos cualquier regularidad rítmica y que tiende a prescindir de la linealidad de la escritura para convertirse en representación icónica y a dejar, por lo tanto, ya de ser verso en sentido estrictamente métrico, continúan otras clases de verso libre, en las que, con o sin juegos tipográficos, se respeta generalmente la escritura lineal y se mantiene una tendencia rítmica dominante continuada o interrumpida tan sólo en ocasiones.

Juan Ramón Jiménez, que también asoció el verso libre a la naturalidad de la prosa y al principio de expresión auténtica de la subjetividad y el ritmo personal, ${ }^{47}$ es el gran y principal maestro de esta clase de verso libre, dominado por ritmos versales y que tanto había de influir en la poesía posterior. Para Juan Ramón, la naturalidad del verso libre, por estar liberado de la rima, facilita la pura expresión personal. Esta idea, repetida una y otra vez por distintos poetas del siglo xx, queda ligada desde muy temprano en Juan Ramón Jiménez al ritmo misterioso y profundo del oleaje marino. A propósito del Diario explica que «en él usé por vez primera el verso libre: éste vino con el oleaje, con el no sentirse firme, bien asentado». ${ }^{48}$ Como ha indicado I. Paraíso, la idea del vaivén del mar asociada al verso libre no es más que una fanta-

47 J.R. Jiménez, Estética y ética estética, Madrid, Aguilar, 1962, p. 308. En algunas conferencias recogidas en su Política poética, como "Poesía y literatura” (1940), "Poesía cerrada y poesía abierta” (1948) y "El romance, río de la lengua española” (1954), desarrolla estas ideas, cuyo germen hay que situar en los años de escritura de Platero y yo y del Diario de un poeta reciencasado. Cfr. J.R. Jiménez, Política poética, edición de G. Bleiberg, Madrid, Alianza, 1982, p. 249.

48 R. Gullón, Conversaciones con Juan Ramón Jiménez, Madrid, Taurus, 1958, p. 84. 
sía juanramoniana, ya que antes del viaje por mar había escrito verso libre tanto en el Diario como en su poesía anterior. ${ }^{49}$ En realidad, Juan Ramón sigue el conocido tópico whitmaniano que asocia el ritmo libre a las olas del mar, tópico repetido por un buen número de poetas anglosajones, y por otros como Mario de Andrade. Para Whitman, el mar mismo es un gran poema versolibrista, cuyas línea son «the liquid, billowy waves, ever rising and falling, perhaps wild with storm, always moving, always alike in their nature as rolling waves, but hardly any two exactly alike in size or mesure». ${ }^{50}$ No lejos de este concepto ondulante del ritmo está la visión de Vicente Huidobro, antes expuesta, o la de Gerardo Diego cuando se refiere a la elasticidad y la espiritualidad del verso, que liga a la música y la idea interior. ${ }^{51}$

La euforia versolibrista experimenta un claro auge hacia finales de la década de los 20, con las poéticas surrealistas y la poesía política de protesta, no sólo en algunos autores del 27 -Alberti, Lorca, Aleixandre, Cernuda-, sino en autores hispanoamericanos como Pablo Neruda, de tanta influencia posterior. Sin embargo, a menudo el versolibrismo de estos autores se ajusta también a alguna pauta rítmica que se interrumpe con fines expresivos. Como demuestran los estudios sobre la métrica de estos y otros autores la base rítmica de sus poemas es indudable, de ahí que se haya hablado, más que de versificación libre, de versificación semilibre, precisamente por la acusada tenden-

${ }^{49}$ Véase I. Paraíso, El verso libre..., pp. 201-202.

${ }^{50}$ Apud P. Fussel, op. cit., pp. 82-83.

${ }^{51}$ Cfr. G. Diego, “Elasticidad y espiritualidad del ritmo”, en VV.AA., Elementos formales en la lírica actual, Santander, U.I.M.P., 1967, pp. 29-44, y "Defensa de la Poesía”, Carmen, 5 (1928), pp. 11-16. Sobre G. Diego, vide F.J. Díez de Revenga, La métrica de los poetas del 27, Murcia, Universidad de Murcia, 1973, pp. 292303; I. Paraíso, "El orden en la pirueta: Notas sobre la métrica libre de Gerardo Diego”, Crisol (Nanterre), 9 (1988), pp. 47-63, y "Retórica y Poesía. Comentario retórico sobre un poema de Gerardo Diego”, en I. Paraíso (coord.), Téchne Rhetoriké. Reflexiones actuales sobre la tradición retórica, Valladolid, Universidad de Valladolid, 1999, pp. 131-149. Sobre la relación entre el ritmo poético y el movimiento de las olas en Rubén Darío y Pablo Neruda, véase A. Sicard, "Mar, ritmo y poesía en Rubén Darío y Pablo Neruda”, en G. Areta Marigó, H. Le Corre, M. Suárez y D. Vives (eds.), Poesía hispanoamericana: Ritmo(s)/métrica(s)/ruptura(s), Madrid, Verbum, 1999, pp. 222-235. 
cia al ritmo endecasilábico, que alcanza incluso al versículo de algunos autores. En este sentido, Rafael Alberti indica: «Todos falsificamos, mejor dicho, trucamos la métrica, cortando el verso por donde nos conviene, o nos viene en gana, con el fin de ofrecer un verso libre, largo, de más nueva apariencia; verso que leído con picardía no pasa de ser, casi constantemente de once a catorce sílabas; al fin, ese mismo que repitiéndose sin consonante la preceptiva literaria llama verso blanco». ${ }^{52}$ También Jorge Luis Borges reconoce la tradicionalidad endecasilábica de su verso libre, aunque conviene advertir que no todo su verso libre es de ritmo endecasilábico. Así, en el prólogo a Elogio de la sombra, después de apuntar las relaciones entre versículo y prosa, afirma: "Yo anhelé alguna vez la vasta respiración de los psalmos o de Walt Whitman; al cabo de los años compruebo, no sin melancolía, que me he limitado a alternar algunos metros clásicos: el alejandrino, el endecasílabo, el heptasílabo». ${ }^{53}$

La ruptura del ritmo silábico, unida ocasionalmente a ciertos cambios acentuales, como sucede, por ejemplo, en el endecasílabo español, es lo que realmente suele ser percibido como versificación libre en la mayor parte de la poesía occidental, y especialmente en la tradición de las lenguas romances. Sería este último tipo de versificación libre el más conservador y el que, a lo largo de todo el siglo xx, más tiempo se ha mantenido y más ha calado en los grandes escritores versolibristas. Ello explica, por ejemplo, la permanencia de las combinaciones basadas en la silva.

Uno de los estudios que, junto al de Amado Alonso sobre Pablo Neruda, ha demostrado ampliamente la tendencia rítmica endecasilábica del verso libre ha sido el de Carlos Bousoño sobre la poesía de Vicente Aleixandre. Sin prescindir de las apoyaturas retóricas, el verso libre o versículo aleixandrino, tal como aparece en Sombra del Paraíso, posee en cuanto al ritmo

\footnotetext{
${ }^{52}$ Rafael Alberti, Poemas diversos (1945-1956), en Poesías completas, Buenos Aires, Losada, 1961, p. 790.

53 J.L. Borges, Obra poética, p. 317. Cfr.I. Paraíso, El verso libre..., p. 376; E. Torre, Métrica española comparada, Sevilla, Servicio de Publicaciones de la Universidad de Sevilla, 2000, pp. 106-107.
} 
“un punto de clasicidad”, que, según Bousoño, es extensible en lo sustancial a toda la obra de Aleixandre y a la versificación libre en general. En el 95\% de los versos de Sombra del Paraíso descubre Bousoño, tras un profundo análisis, la presencia de los ritmos endecasilábicos sucesivos o yuxtapuestos en el verso extenso o versículo, que a veces se suman y otras se solapan, de modo que la novedad aleixandrina respecto a épocas anteriores, como el modernismo, residiría sólo en la reunión en un solo versículo de diferentes versos breves de tipo endecasilábico. Las posibles irregularidades dentro del general predominio del ritmo endecasilábico se asumirían perfectamente dentro de la estructura poemática, ya que las unidades rítmicas dislocadas quedan absorbidas por la masa rítmica mayoritaria del poema. Es básicamente lo que sucede también en los escasos textos con alguna disonancia del Diario de un poeta reciencasado de Juan Ramón Jiménez. La presencia de estos versos irregulares se explicaría por motivos puramente estéticos y expresivos. ${ }^{54}$

En la poesía actual se siguen las directrices marcadas a partir de la postguerra española con una clara vuelta a formas tradicionales con momentos de auge versolibrista menos frecuentes. Luis Antonio de Villena ha estudiado recientemente el panorama poético de los últimos veinticinco años, que vendría determinado por una serie de poetas muy heterogéneos, pero que comparten el deseo de recuperar la tradición, algo que sucede especialmente en las distintas tendencias poéticas que surgen en los años ochenta. Una consecuencia lógica de esta vuelta a los valores tradicionales es la recuperación de la métrica, aunque, según Villena, el versolibrismo no esté ausente de la tradición clásica. ${ }^{55}$

¿Cómo entender entonces el problema del ritmo en la teoría

${ }^{54}$ Véase C. Bousoño, La poesía de Vicente Aleixandre, segunda edición corregida y aumentada, Madrid, Gredos, 1968, pp. 281-286: A. Alonso, Poesía y estilo de Pablo Neruda (1951), Barcelona, Edhasa, 1979, passim; P. García Carcedó, "Variedad rítmica en la poesía de Pablo Neruda”, en J. Marco (ed.), XXIX Congreso del Instituto Internacional de Literatura Iberoamericana, Universidad Complutense de Madrid, 1992, vol. II, Barcelona, P.P.U., 1994, pp. 659-665.

${ }^{55}$ Véase L.A. de Villena, Teorías y poetas. Panorama de una generación completa en la última poesía española, 1980-2000, Valencia, Pre-Textos, 2000, pp. 24 y 75. 
del siglo xx? Partiendo de las primeras opiniones de los poetas, la crítica que se ha ocupado del verso libre a menudo ha continuado algunos de los tópicos versolibristas. En este sentido, casi la totalidad de los críticos explica la aparición y desarrollo del verso libre como el resultado de la pura expresión del ritmo personal, del pensamiento y las emociones individuales. ${ }^{56}$

En su estudio sobre Pablo Neruda, por ejemplo, Amado Alonso relaciona el ritmo interior del verso libre con el de la prosa, a lo que se añade, fuera ya de la lógica prosística -y en ello consistiría el ritmo poético libre-, la manifestación lineal de «las intuiciones que dan salida y forma al sentimiento». La vinculación con la prosa se evidenciaría en la manera de expresión, generalmente en entidades sintácticas independientes, como querían los primeros versolibristas franceses. Se trata, en parte, de un ritmo regido por moldes sintácticos, pero unidos entre sí porque el impulso emocional los enlaza, como en una cadena. ${ }^{57} \mathrm{La}$ expresión de este ritmo en cadena, presidido por impulsos intuicionales o emocionales internos, deriva en imágenes encadenadas, enumeraciones, repeticiones de determinados elementos de un verso a otro, en un juego de tensiones y distensiones, encabalgamientos -cuando los hay- de gran valor expresivo, y la repetición obsesiva del tema. ${ }^{58}$ Se trata de lo que Paraíso llama la equivalencia afectiva de imágenes, dada en muchos casos por ese movimiento envolvente del ritmo en cadena, que sería el soporte básico del llamado verso libre de pensamiento. ${ }^{59}$ Es lo que sucede, por ejemplo, en los siguientes versos citados por Amado Alonso en su estudio:

${ }^{56}$ Cfr. J. Domínguez Caparrós, op. cit., p. 179; C. Scott, Reading the Rhythm. The Poetics of French free Verse. 1910-1930, Oxford, Clarendon Press, 1993, p. 6; G.B. Cooper, Mysterious Music. Rhythm and free Verse, Stanford, Stanford University Press, 1998, pp. 30-35; V. Zirmunskij, op. cit., pp. 26-27; I. Paraíso, El verso libre..., p. 55; P. Henríquez Ureña, “En busca del verso puro”, Estudios de versificación española, Buenos Aires, Universidad de Buenos Aires-Instituto de Filología "Doctor Amado Alonso”, 1961, p. 254.

${ }^{57}$ A. Alonso, op. cit., p. 88.

${ }^{58}$ Vide ib., pp. 89-114.

${ }^{59}$ Cfr. I. Paraíso, El verso libre..., p. 31. 
Si solamente me tocaras el corazón

si solamente pusieras tu boca en mi corazón, tu fina boca, tus dientes, si pusieras tu lengua como una flecha roja allí donde mi corazón polvoriento golpea, si soplaras en mi corazón, cerca del mar, llorando, sonaría con un ruido oscuro, con sonido de ruedas

como aguas vacilantes,

[de tren con sueño como el otoño en hojas, como sangre, con un ruido de llamas húmedas quemando el cielo, sonando como sueños o ramas o lluvias, o bocinas de puerto triste, si tú soplaras en mi corazón, cerca del mar, como un fantasma blanco, al borde de la espuma, en mitad del viento, como un fantasma desencadenado, a la orilla del mar llorando.

El poema revela, por otra parte, una tendencia al ritmo endecasilábico, interrumpido por algunos versos:

Si solamente me tocaras el corazón

si solamente pusieras tu boca en mi corazón,

tu fina boca, tus dientes, si pusieras tu lengua como una flecha roja allí donde mi corazón polvoriento golpea, 8 si soplaras en mi corazón, cerca del mar, llorando, $7+7$ $9+7$ sonaría con un ruido oscuro, con sonido de ruedas de tren con sueño como aguas vacilantes, como el otoño en hojas, $10+7$ como sangre, con un ruido de llamas húmedas quemando el cielo, sonando como sue ños o ramas o lluvias, o bocinas de puerto triste, si tú soplaras en mi corazón, cerca del mar, como un fantasma blanco,

$10+7+5$

7

7

$4(7+4: 11)$

$9+5$

14

9

$11+5$

7 
al borde de la espuma, $\quad 7$

en mitad del viento, $\quad 6$ como un fantasma desencadenado, a la orilla del mar llorando.

A este marcado ritmo de pensamiento, de naturaleza retórica, Amado Alonso añade en la práctica del verso libre de Neruda la presencia generalizada de un canon métrico, normalmente alrededor del ritmo endecasilábico, que organiza métricamente el texto. ${ }^{60}$

Caracterizado también como expresión del sentimiento y la pulsión personal, siguiendo el tópico de la lírica asociada a la subjetividad, aparece el verso libre en Tomás Navarro Tomás, para quien el único elemento tradicional que el versolibrismo admite es el ritmo, que «se funda en la sucesión de los apoyos psicosemánticos que el poeta, intuitiva o intencionalmente, dispone como efecto de la armonía interior que le guía en la creación de su obra». ${ }^{61}$ A partir de esta idea nuclear, advierte que el verso libre no excluye la presencia del verso regular, de la rima o de la estrofa. ${ }^{62}$

Respecto a Vicente Aleixandre, Dámaso Alonso indica cómo su verso libre a menudo se remansa en la «conocida música de los endecasílabos tradicionales» ${ }^{63}$-como años más tarde concluirá Bousoño respecto a Sombra del Paraíso- y hace

${ }^{60}$ A. Alonso, op. cit., pp. 87 y 114.

${ }^{61}$ T. Navarro Tomás, op. cit., p. 454.

${ }^{62}$ Véase $i b .$, pp. 41 y 500; I. Paraíso, El verso libre..., p. 40. No obstante, más adelante sufre un cambio en su opinión sobre el verso libre. Aparte del verso libre con tendencia al ritmo endecasilábico, el verso libre verdaderamente amétrico, consecuente con su espontaneidad -el arritmo de Jaimes Freyre-, cae para Navarro Tomás fuera del concepto de verso y se aproxima claramente a la prosa, justificándose sólo como verso por su apariencia tipográfica. Vide T. Navarro Tomás, "En torno al verso libre” (1970), en Los poetas en sus versos. Desde Jorge Manrique a García Lorca (1973), Barcelona, Ariel, 1982, pp. 381-387, y “Apuntes sobre versificación moderna”, en VV.AA., Homenaje a la memoria de Don Antonio Rodríguez-Moñino. 1910-1970, Madrid, Castalia, 1975, pp. 514-515.

63 D. Alonso, Poetas españoles contemporáneos, tercera edición aumentada, Madrid, Gredos, 1965, p. 278. 
notar igualmente el "énfasis retórico", presente en otros poetas versolibristas de su generación -Alberti, Lorca-, que se plasma en enumeraciones, repeticiones, etc., relacionadas con las obsesiones oníricas en Espadas como labios y La destrucción o el amor, ${ }^{64}$ aunque este ritmo sintáctico o de pensamiento aparece igualmente en otros poemarios versolibristas no surrealistas. Asimismo señala la importancia del ritmo interior. El recurso a explicar la ametría versolibrista como resultado del ritmo personal es, como se ve, frecuente en los estudios métricos y se vincula igualmente al ritmo de pensamiento, marcado por la unidad sintáctica de cada verso, las repeticiones y el paralelismo además de otros elementos retóricos.

Al prescindir de los factores métricos, la explicación rítmica del verso libre se hace a veces a partir del dominio de la estilística. La efectiva dificultad y la variabilidad del verso libre han llevado a no pocos críticos a explicar la versificación libre teniendo en cuenta el amplio concepto de ritmo de pensamiento. ${ }^{65}$

${ }^{64}$ Cfr. ib., pp. 278 y 284-287.

${ }^{65}$ Dentro de los escasos estudios de conjunto dedicados en España al verso libre, Francisco López Estrada parte de la premisa del ritmo interior tanto en su Métrica española del siglo XX, de 1969, como en un artículo anterior titulado "La métrica nueva” (1967). En ambos estudios pretende desligar la nueva poesía, que él asocia especialmente a la vanguardia, de la métrica tradicional. Cfr. F. López Estrada, "La métrica nueva", en VV.AA., Elementos formales en la lírica actual, ed. cit., pp. 104-105, y Métrica española del siglo XX, Madrid, Gredos, 1969, pp. 99-111 y 120-122. Fernando Lázaro Carreter ha explicado el verso libre, diferenciándolo de la prosa, a partir de las repeticiones sintácticas y en relación con la función poética de Jakobson, justificando el ritmo a partir del impulso dictado por la emoción artística, en la línea de Amado Alonso. Véase F. Lázaro Carreter, "Función poética y verso libre” (1971), en Estudios de poética (La obra en sí), Madrid, Taurus, 1976, pp. 58-61. Ya R.D. Bassagoda mencionó algunos procedimientos estilísticos del verso libre, como frases repetidas, paralelismos, metáforas e imágenes, etc. Cfr. R.D. Bassagoda, "Del alejandrino al verso libre”, Boletín de la Academia Argentina de Letras, XVI, 58 (1947), pp. 110-111; S. Gili Gaya, “Observaciones sobre el ritmo de la prosa”, en Estudios sobre el ritmo, edición de I. Paraíso, Madrid, Istmo, 1993, pp. 55-56; A. Quilis, "Sobre el verso libre en español”, en J. Romera, A. Lorente y A.M. Freire (eds.), Homenaje al Profesor José Fradejas Lebrero, t. II, Madrid, U.N.E.D., 1993, pp. 896-900, y Métrica española, Barcelona, Ariel, 1984, p. 165; F.J. Díez de Revenga, op. cit., p. 277.; I. Paraíso, El verso libre...; J. Cohen, op. cit., pp. 30-43; J. Domínguez Caparrós, Métrica y poética. Bases para la fundamentación de la métrica en la teoría literaria moderna, Madrid, U.N.E.D., 1988, p. 28, Métrica española, Madrid, Síntesis, 
Isabel Paraíso entiende también que los factores semánticos y sintácticos son esenciales en la explicación del ritmo poético. Así, en su amplia tipología sobre el verso libre se refiere a la versificación paralelística, que se apoyaría en el ritmo de pensamiento. Independientemente de que esta versificación paralelística contenga o no ritmos fónicos, se caracteriza sobre todo por «un retorno ideológico, bien en forma positiva (paralelismo sinonímico), en forma negativa (paralelismo antitético), o en forma de emblema o símil que se desarrolla en el verso siguiente (paralelismo emblemático). Este retorno se plasma frecuentemente en recurrencias sintácticas (isocolos de todo tipo: en quiasmo, en paromoeosis, etc.) y en recurrencias léxicas ("repetitio” en sus múltiples formas: geminación, anáfora, complexión, epímone, etc.) o en recurrencias semánticas (enumeración, acumulación, sinonimia, percusión, etc.)». ${ }^{66}$ La retórica explicaría, pues, en buena medida la "poeticidad” de estos textos.

Paraíso considera, además, en relación a la versificación que se basa en el ritmo de pensamiento, el verso de imágenes acumuladas o yuxtapuestas libre, en el que predominan las

1993, p. 51 y Diccionario de métrica española, pp. 176-179; E. Alarcos Llorach, "Secuencia sintáctica y secuencia rítmica”, en VV.AA., Elementos formales en la lírica actual, ed. cit., pp. 11-16, y La poesía de Blas de Otero, Madrid, Gredos, 1966; J. Silkin, op. cit., pp. 7 y ss.; G.B. Cooper, op. cit., pp. 30-35 y 101-109; P. Fussel, op. cit., pp. 78-80; O. Belic, op. cit., pp. 192-193 y 582; P. Jauralde Pou, "Poesía española actual. La cuestión métrica”, Voz y Letra. Revista de Literatura, X, 1 (1999), p. 119; Véase A. Kibédi-Varga, "Syntaxe et rythme chez quelques poètes contemporains”, en M. Parent (ed.), op. cit., pp. 176-177 y 178-181; Ch.O. Hartman, op. cit., pp. 81-103; K.M. Kohl, op. cit., pp. 9-12, 252-254. Si bien es cierta, según se ha visto ya, la profunda importancia de ciertos elementos retóricos, es excesivo hablar de desprecio hacia las pautas versales dentro de la poesía contemporánea, sobre todo si se tiene en cuenta la influencia métrica tradicional en la poesía de los últimos años. En este sentido, Esteban Torre considera que en el poema la forma del contenido es esencial en la conformación del ritmo de pensamiento, aunque son las iteraciones fónicas, en concreto el número de sílabas y la disposición del acento, los fundamentos rítmicos del verso. A ello se añadirían secundariamente otras repeticiones fónicas importantes, como la rima o la aliteración. Vide E. Torre, El ritmo del verso (Estudios sobre el cómputo silábico y la distribución acentual, a la luz de la Métrica Comparada, en el verso español moderno), Murcia, Servicio de Publicaciones de la Universidad de Murcia, 1999, p. 12, y Métrica española comparada, p. 55.

${ }^{66}$ I. Paraíso, La métrica española..., p. 204. Cfr. I. Paraíso, El verso libre..., p. 399. 
imágenes reiteradas y, sobre todo, la metáfora, ${ }^{67}$ y que es frecuente en la vanguardia. Se caracteriza por prescindir del paralelismo sintáctico para dar el protagonismo a una «red de imágenes afectivamente equivalentes, que traducen un especial estado anímico del poeta». Este tipo de composiciones suele aparecer con una disposición tipográfica anómala, propia de los juegos vanguardistas, y tiende a eliminar cualquier rasgo métrico, por lo que habitualmente «su ritmo no radica en la forma versal». ${ }^{68}$ Supone, pues, un paso más extremo que el versículo whitmaniano en la efectiva destrucción del concepto de verso. ${ }^{69}$ El juego de las imágenes es evidente en el siguiente fragmento del poema "Mar" de Gerardo Diego: ${ }^{70}$

Cuántas tardes viudas

Pero ninguna arrastraron sus mantos sobre el mar

como tú tarde grave

hermana mía

señorita de compañía

dolorosa como una

Aquel poema desplegó sus velas y escribió con la quilla sus estelas versos horizontales salpicados de acentos que cantan sacudidos por los vientos

Obsérvese, sin embargo, que, aparte de la rima, hay también un claro ritmo endecasilábico, con versos de cinco sílabas -versos 3 y 6-, siete sílabas -versos 1, 7, 11 y 12-, nueve sílabas -verso 8- y once sílabas -versos 2, 9, 10 y 13-. Por su parte, los versos 4 y 5 , de cuatro sílabas tomados separadamente, si se unen en la lectura forman un heptasílabo.

${ }^{67}$ Cfr. I. Paraíso, La métrica española..., p. 190.

${ }^{68}$ I. Paraíso, El verso libre..., p. 400. Véase La métrica española..., p. 207.

${ }^{69}$ Cfr. I. Paraíso, El verso libre..., p. 284. 
El ritmo de pensamiento en sus distintas vertientes, no obstante, es perceptible en otras composiciones en verso regular, como ya vio Carlos Bousoño en "La correlación en la poesía española moderna”. ${ }^{71}$ El paralelismo -apunta Domínguez Caparrós- es frecuente no sólo en el verso libre, sino "en toda manifestación poética en verso". ${ }^{72}$ Pero igualmente puede encontrarse como recurso rítmico de la prosa, por lo que en sí mismo no es, desde luego, como sucede también con la acumulación de imágenes caóticas, un procedimiento que justifique el verso como tal, aunque pueda contribuir a su "poeticidad".

José Domínguez Caparrós se ha referido frecuentemente al ritmo sintáctico o de pensamiento no sólo respecto al problema del encabalgamiento, sino a las repeticiones léxicas, de estructuras sintácticas, etc. Sobre el verso libre, que define como verso «caracterizado porque la falta la regularidad en el número de sílabas no está sometida a ningún límite ni a ninguna norma acentual», señala que su caracterización rítmica «reside en una segmentación del discurso basada fundamentalmente en la entonación», ${ }^{73}$ segmentación que permite aislar unidades de imágenes, de figuras, de pensamiento, las cuales derivan de la intuición que expresa el sentimiento personal. Aparte de los elementos fónicos, las repeticiones sintácticas y semánticas son en el verso libre esenciales, ya que en él «el elemento rítmico dominante es de índole sintáctica, semántica o visual». ${ }^{74}$ Junto a estos aspectos, indica la amplia diversidad versolibrista y la posible presencia de estructuras regulares y tradicionales, o de la rima, al lado de versos arrítmicos. Así sucede en el ejemplo de verso libre del Canto General de Neruda, que él mismo ofrece en su Métrica española ${ }^{75}$ donde el ritmo se funda en unidades

${ }^{70}$ Véase I. Paraíso, La métrica española..., pp. 190 y 207.

${ }^{71}$ Véase C. Bousoño, “La correlación en la poesía española moderna”, en D. Alonso y C. Bousoño, Seis calas en la expresión literaria española, tercera edición aumentada, Madrid, Gredos, 1963, p. 269.

72 J. Domínguez Caparrós, Métrica española, p. 51.

${ }^{73}$ Véase J. Domínguez Caparrós, Diccionario de métrica española, pp. 187-188, y Métrica española, pp. 45-46 y 183.

${ }^{74} \mathrm{Ib}$., p. 46.

${ }^{75}$ Vide J. Domínguez Caparrós, Diccionario de métrica española, p. 18, y Métrica española, pp. 186-187. 
sintácticas y de contenido, aunque es evidente, además, la medida endecasilábica de los versos, de 7, 11 y 14 sílabas:

Qué luna como una culata ensangrentada, qué ramaje de látigos, qué luz atroz de párpado arrancado te hacen gemir sin voz, sin movimiento, rompen tu padecer sin voz, sin boca:

oh, cintura central, oh, paraíso de llagas implacables.

De noche y día veo los martirios, de día y noche veo al encadenado, al rubio, al negro, al indio escribiendo con manos golpeadas y fosfóricas en las interminables paredes de la noche.

Conviene insistir en que el llamado ritmo de pensamiento no puede ser considerado con propiedad como un sistema de versificación, ni es algo exclusivo ni intrínseco a la poesía libre. ¿Cómo decidir entonces en qué consiste el ritmo del versículo y del verso libre? Es éste una cuestión continuamente debatida. El problema de decidir si un versículo ha de estudiarse como prosa o como verso largo producto de la suma de distintos versos cortos dependerá, sin duda, de sus estrictas cualidades métricas o de la ausencia de éstas.

Como ocurre en la silva juanramoniana, también el versículo se explica muchas veces por el ritmo endecasilábico. Con apariencia de verso libre el siguiente poema de Antonio Carvajal se ajusta, en general, a la regularidad rítmica, donde une el versículo y el verso de ritmo endecasilábico:

Te busco en esta última mañana de verano, tan grata a los sentidos, con jazmines en ramas y en el suelo, y evoco tu dolor y tus gozos

que pobremente fueron míos. Oigo el rumor del mundo, algo lejano, que no apaga ni mis pulsos ni mi respiración, y sé que vivo

por tu recuerdo, porque tú me hiciste

de ti, fruto de amor y de esperanza,

y yo me sé nacido de ese amor hacia otro y de ese otro que se fundió 
contigo y sois mi vida.

Y ahora miro al cielo con mejillas de lluvia

y en el azul que empañan leves nubes

no distingo tu rostro

y me faltan tus manos que crucé en gesto último de súplica y entrega, y alzo la voz, aun a sabiendas de que no puedes oírme, de que no volverás esos tus ojos

misericordiosos a esta pobre criatura que tú hiciste,

esta voz que te dice

madre,

no puedo perdonarte

que me dejaras solo.

La longitud, cercana a la prosa, de los versículos no impide la percepción de los versos endecasilábicos perfectamente regulares:

Te busco en esta última // mañana de verano, // tan grata a los sentidos, // con jazmines en ramas // y en el suelo, y evoco // tu dolor y tus gozos $7+7+7+7+7+7$

que pobremente fueron míos. // Oigo el rumor del mundo, // algo lejano, que // no apaga ni mis pulsos // ni mi respiración, y sé que vivo $9+7+7+7+11$

por tu recuerdo, porque tú me hiciste 11

de ti, fruto de amor y de esperanza, 11

y yo me sé nacido // de ese amor hacia otro y de ese otro // que se fundió contigo y sois mi vida. $7+11+11$

Y ahora miro al cielo // con mejillas de lluvia 7+7

$\mathrm{y}$ en el azul que empañan leves nubes 11

no distingo tu rostro 7

y me faltan tus manos // que crucé en gesto último // de súplica y entrega, $7+7+7$

y alzo la voz, // aun a sabiendas de // que no puedes oírme, // de que no volverás esos tus ojos 5+7+7+11

misericordiosos a esta // pobre criatura que tú hiciste, 9+9

esta voz que te dice 7

madre, 2 
no puedo perdonarte 7

que me dejaras solo. 7

La impresión de regularidad y periodicidad del ritmo del verso libre y del versículo reside en la continua aproximación a unos modelos conocidos por el lector competente. ${ }^{76}$ En muchos casos, la tradición métrica está claramente presente en el versolibrismo. Ya Henri Morier demostró en su estudio sobre el verso libre francés la base tradicional del mismo, que se erige en el fundamento de su teoría sobre el versolibrismo. ${ }^{77}$ Independientemente de las dificultades que pueda plantear la escansión de los versos libres, es necesario un estudio métrico de los mismos, único modo de llegar a discernir si se trata o no de versos, sean cuales fueran sus componentes métricos. ${ }^{78}$ Estudiar el verso libre prescindiendo de la base del verso clásico es obviar una gran parte de la poesía versolibrista que se asienta en la tensión y continua confrontación con el verso tradicional.

${ }^{76}$ Vide J. Cohen, op. cit., pp. 217-218; F. Deloffre, "Versification traditionnelle et versification libérée d'après un recueil d’Yves Bonnefoy”, en M. Parent (ed.), op. cit., p. 55, y "Vers libre et vers rénové”, en Le vers français, París, SEDES, 1973, pp. 156-167.

${ }^{77}$ Cfr. H. Morier, Le Rythme du vers libre symboliste, étudié chez Verhaeren, Henri de Régnier, Viélé-Griffin, et ses relations avec le sens, vol. I, Ginebra, Les Presses Académiques, 1943, passim; M. Parent, art. cit., loc. cit., p. 292; C. Scott, Vers libre: The Emergence..., pp. 92-94, y A Question of Syllables, pp. 158-175; D. Grojnowski, "Poétique du vers libre: Derniers Vers de Jules Laforgue”, Revue de'Histoire Littéraire de la France, LXXXIV, 3 (1984), pp. 405-410; A. García Ortega, “Jules Laforgue: Vida y tedio”, Revista de Occidente, $74-75$ (1987), pp. 231-233; J. Filliolet, "Problématique du vers libre”, Language Français, 23 (1974), p. 71; J. Mazaleyrat, “La tradition métrique dans la poésie d’Éluard”, en M. Parent (ed.), op. cit., pp. 25-32.

${ }^{78}$ E. Torre, El ritmo del verso, pp. 12-13. Véase también E. Torre, Métrica española comparada, p. 23. Cfr. I. Tinianov, El problema de la lengua poética (1924), Buenos Aires, Siglo XXI, 1972, pp. 20-39; H. Morier, op. cit., p. 19. 